Johannes Koder (Wien)

(iD) https://orcid.org/0000-0002-2094-5090

\title{
Time as a Dimension of Byzantine IDentity
}

\section{Identity in Byzantium}

$I^{2}$ dentity - going back to the Byzantine Congress in Copenhagen ${ }^{1}$ (1996) - is a current issue of research in Byzantine Studies. Identity is closely linked with a sense of belonging ${ }^{2}$. Though the systems of cultural, religious, moral and ideological rules differ in the different regions of the Mediterranean, they are all deeply rooted in a fundamental need for belonging and express a need for communication with like-minded individuals. Hence, it is not astonishing that in Medieval Studies the development of a collective identity is of particular interest given the mythical ethnogenesis of many nations before the very beginning of their "history"3. With respect to ethnogenesis, Byzantium is one of the rare exceptions: it has no mythical origin because its prehistory is an amalgam of Christian ideology and the later history of the Roman Empire ${ }^{4}$.

Ancient, Byzantine and modern Greek identity have common elements, but also significant differences. In particular, the idea of an unbroken continuum from the Ancient past to the Modern Greek present - which was at least in part provoked or intensified by Jakob Philipp Fallmerayer's theories - was (and still is) under discussion ${ }^{5}$.

\footnotetext{
${ }^{1}$ Byzantium. Identity, Image, Influence. XIX. International Congress of Byzantine Studies, Major Papers, ed. F. Fledelius, Copenhagen 1996, and specifically: Plenary Session I - The Identity of Byzantium. ${ }^{2}$ Always a rewarding topic for politological and anthropological scientists, it actually has gained currency again, see e.g. B. Latour, M. Lilla, Heimat: Was bedeutet sie heute?, "Die Zeit" Nr. 12, March 14,2019 , p. 40sq.

${ }^{3}$ See: e.g., P.J. Geary, The Myth of Nations. The Medieval Origins of Europe, Princeton 2002, and the overview in Integration und Herrschaft. Ethnische Identitäten und soziale Organisation im Frühmittelalter, ed. W. PohL, M. Diesenberger, Wien 2002 [= FGM, 3].

${ }^{4}$ See: J. Koder, Byzanz, die Griechen und die Romaiosyne - eine "Ethnogenese" der "Römer"?, [in:] Typen der Ethnogenese unter besonderer Berücksichtigung der Bayern, vol. I, ed. H. WolfRAM, W. PoHL, Vienna 1990 [ = DKAW.PhH, 201], p. 103-111; IDEM, Byzantium as Seen by Itself - Images and Mechanisms at Work, [in:] Proceedings of the $22^{\text {nd }}$ International Congress of Byzantine Studies Sofia, 22-27 August 2011, I. Plenary Papers, Sofia 2011, p. 69-81.

${ }^{5}$ See: e.g., T.G. Zervas, The Making of a Modern Greek Identity. Education, Nationalism, and the Teaching of a Greek National Past, [New York] 2012 [= EEM, 790], and basically E. НовsвAwm, The Invention of Tradition, Cambridge 1997.
} 
For the Byzantines in the Eastern Empire, the self-definition as Romaioi ("Romans") had dominated since the $4^{\text {th }}$ century ${ }^{6}$. They used this term, mostly without too much reflection, in order to express their belonging to the Christian Greek Roman empire. To be a Roman was normal; it did not express a particular relationship to ancient Rome or any conscious sense of ethnic belonging, but more or less a political and ideological superiority and, as such, a delimitation from other empires or states. The name Romaioi was adopted and adapted into $R \hat{u} m \hat{\imath}$ since late antiquity by the Syrians and the Arabs, and later also by Turkish tribes. Arabic scholars and writers made a clear distinction between the Byzan-

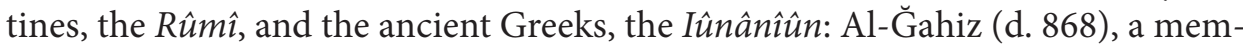
ber of the 'House of Wisdom' (bait al-hikma) in Bagdad, denied their hellenic tradition, maintaining that the ancient Î̂nânîun had been savants ("ulamā), whereas the $R \hat{u} m \hat{\imath}$ were only artisans (șunnä') ${ }^{7}$.

The ancient Greek term for identity is tautotes. Its notion was discussed in its traditional meaning, in contrast to the opposite heterotes ("otherness") ${ }^{8}$, also by Christian authors since Late Antiquity ${ }^{9}$ (e.g. in Clemens of Alexandria's Stromata $^{10}$ and in Damascius' Parmenides ${ }^{11}$ ). The approach in the Doctrina patrum

\footnotetext{
${ }^{6}$ Later also Romioi, to be found in written sources since the $16^{\text {th }}$ century, see Georgius Chortatzes,

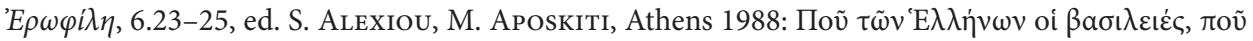

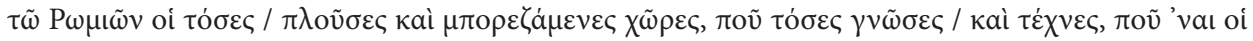

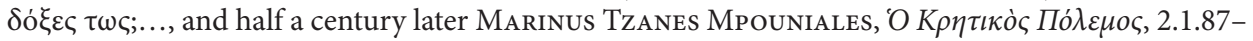

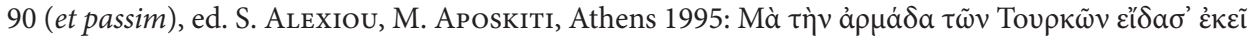

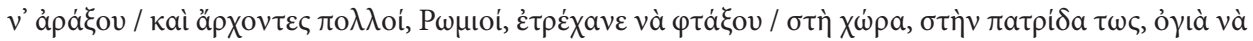

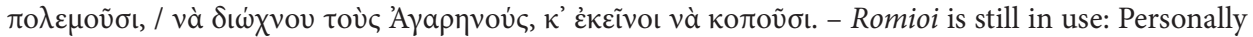
I remember the quarrel of two Greek fisherman in the early seventies of the $20^{\text {th }} \mathrm{c}$., ending with the

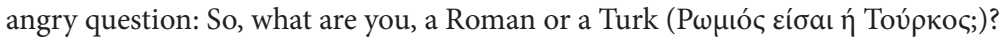

${ }^{7}$ J. Koder, Griechische Identitäten im Mittelalter. Aspekte einer Entwicklung, [in:] Byzantium State and Society. In Memory of Nikos Oikonomides, ed. A. AvrameA, A. Laiou, E. Chrysos, Athens 2003, p. 297-319; IDEM, Remarks on the Linguistic Romanness in Byzantium, [in:] Transformations of Romanness, ed. W. Pohl, C. Gantner, C. Grifoni, M. Pollheimer-Mohaupt, Berlin-Boston 2018 [= MillSt, 71], p. 111-121. - NB. șunnä', not sunna ("usual practice").

${ }^{8}$ Mainly for ideological and religious aspects of otherness see C.D. Merantzas, ANA-X $\Omega P A(-H)$

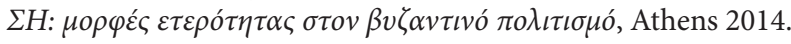

${ }^{9}$ Most of the following quotations from Greek texts are owed to the Thesaurus Linguae Grae$c^{\oplus} e^{\oplus}$ Digital Library, ed. M.C. Pantelia, University of California, Irvine, http://www.tlg.uci.edu [II-III 2019].

${ }^{10}$ Clemens Alexandrinus, Stromata, 8.6.19.5sq, [in:] Clemens Alexandrinus, vol. II-III, ed.

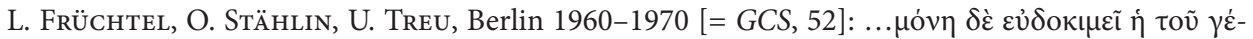

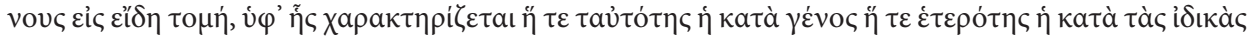

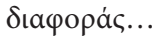

${ }^{11}$ Damascius, In Parmenidem, [in:] Damascii successoris dubitationes et solutiones, vol. II, ed. C.É.

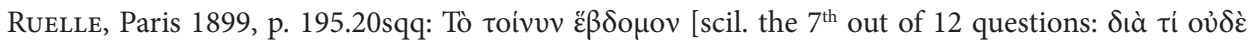

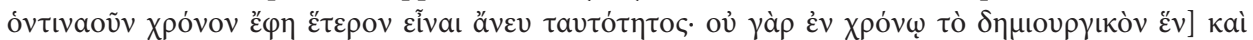

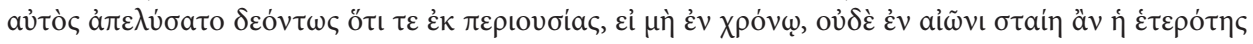

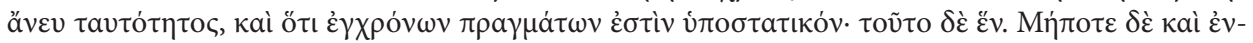


was influential on others; its content was later received by John of Damascus and Michael Psellus ${ }^{12}$. The Doctrina patrum explains the three modoi of difference between identity and otherness as follows ${ }^{13}$ :

Identity is the indistinguishability, according to which the sense of the indicated term owns in every respect its uniqueness and knows in no way any difference. One must know that the identity is understandable in three modes. It is identical with kind... it is also identical with species... finally, it is identical with number... The difference is also understandable threefold: It is a difference in kind and species and again number.

In later centuries, Michael Psellus ${ }^{14}$ and John Italus ${ }^{15}$ speak about the contrast of tautotes vs. heterotes as a subdivision of genos, whereas, for example, PseudoZonaras defines tautotes separately ${ }^{16}$ from "otherness", a term which he expresses primarily with diaphora ${ }^{17}$.

Byzantine scholars, however, did not use the term tautotes in the meaning of "identity", as it is understood nowadays in social and political sciences, namely, the sum of beliefs about oneself, in particular the individual feeling as a personality

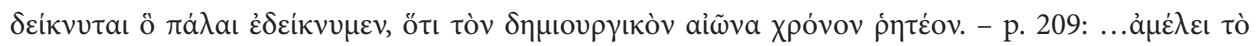

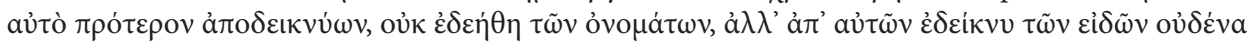

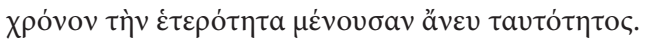

${ }_{12}$ IoAnnes Damascenus, Fragmenta philosophica, 10, [in:] Die Schriften des Johannes von Damaskos, vol. I, ed. P.B. Kotter, Berlin 1969 [= PTS, 7]; Michael Psellus, Theologica, op. 24, vol. I, ed. P. Gautier, Leipzig 1989, vol. II, ed. J.M. Duffy, L.G. Westerink, Munich-Leipzig 2002 (cetera: Michael Psellus, Theologica).

${ }^{13}$ Doctrina patrum de incarnatione verbi, ed. F. Diекамт, Münster 1907 (cetera: Doctrina patrum),

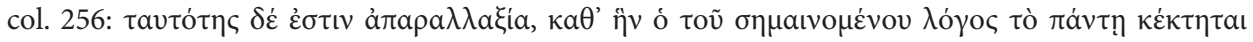

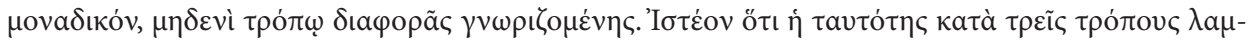

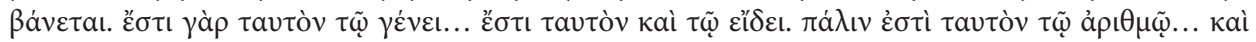

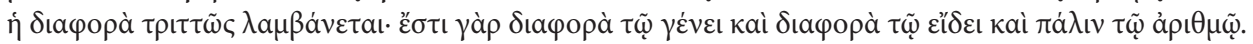

${ }^{14}$ Michael Psellus, Opuscula philosophica minora, vol. II, Opuscula psychologica, theologica, dae-

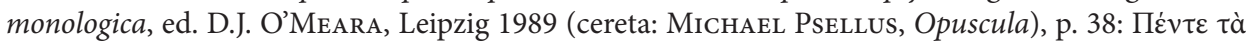

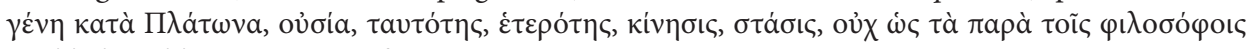

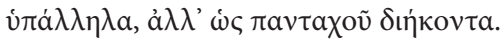

${ }^{15}$ IoAnnes Italus, Quaestiones quodlibetales ('A

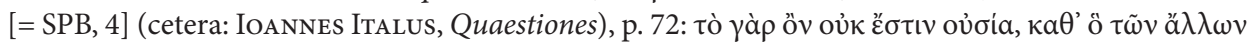

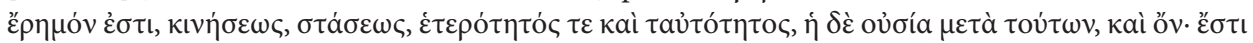

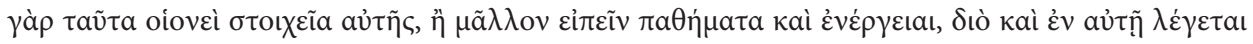
عĩval.

${ }^{16}$ Pseudo-Ioannes Zonaras, Lexikon, tau 1712, ed. J.A.H. Tittmann, Leipzig 1808 (cetera: Pseu-

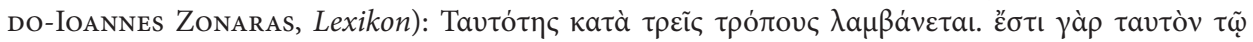

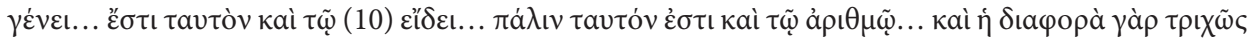

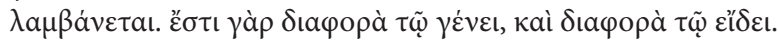

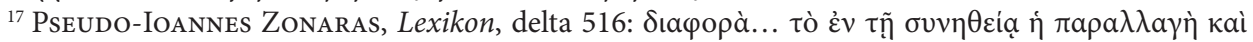

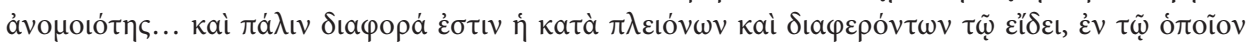

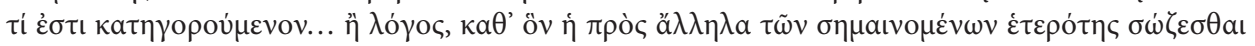

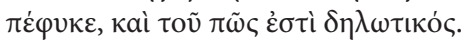


or - in the case of collective identity - as belonging to a social, ethnic, or cultural group. Nevertheless, we observe some interest in collective identity, though expressed in other terms: an informative example is Nicephorus Blemmydes in the $13^{\text {th }}$ century. He discusses the meanings of génos and observes, that génos describes the origin (arche) of a person or group, and he makes the following distinction:

The meanings of 'genos' may differ. 'Genos' may refer to the origin of each one's provenance, be it of his procreator or his home... Hence, the origin of the provenance is dual, natural and local ${ }^{18}$.

Fundamental manifestations of any dimension of identity - and in particular collective identity - are language ${ }^{19}$ (including culture) ${ }^{20}$, religious (and political) commitment ${ }^{21}$, and space (Greek keywords for local regional and supraregional

${ }^{18}$ Nicephorus Blemmydes, Epitome logica, [in:] PG, vol. CXLII, col. 753: ...Tà oquaıvó $\mu \varepsilon v a$ toṽ

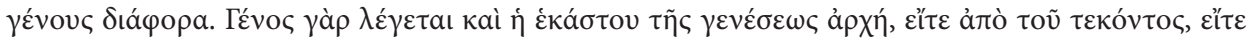

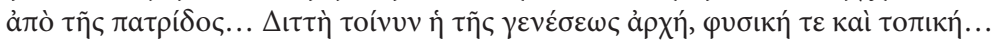

${ }^{19}$ Not only Greek and Latin, but also - regionally and chronologically differentiated - more than a dozen other languages: Albanian, Caucasian Albanian, Arabic, Armenian, Coptic, Georgian, Gothic, Greek, Hebrew, Latin and Romance languages (e.g. Vlach), Persian, southern Slavic languages, SyroAramaic, many of them in dialectal variations. Maximus Homologetes' distinction between religion and language (Maximus Homologetes, Relatio motionis, [in:] PG, vol. XC, col. 128) is interesting:

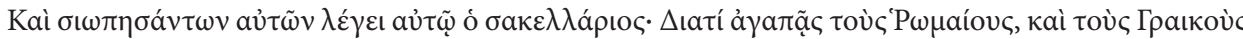

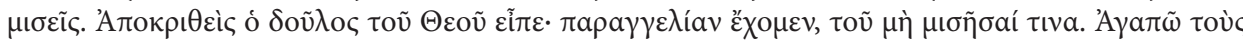

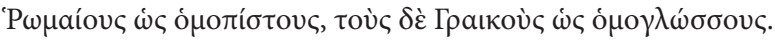

${ }^{20}$ For language and culture, see: From Hellenism to Islam. Cultural and Linguistic Change in the Roman Near East, ed. H.M. Cotton, C. Hoyland, J.C. Price, D.J. Wasserstein, Cambridge 2009;

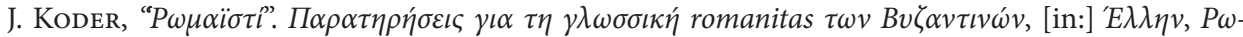

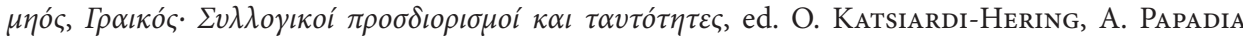
Lala, K. Nikolaou, V. Karamanolakis, Athens 2018, p. 73-84; IDEM, Sprache als Identitätsmerkmal bei den Byzantinern. Auf-isti endende sprachenbezogene Adverbien in den griechischen Quellen, APHK 147, 2, 2012, p. 5-37; IDEM, Die Hellenis als Mitte der Ökumene: Theodoros Laskaris über den Ursprung von Philosophie, Weisheit und Wissenschaft, [in:] Myriobiblos. Essays on Byzantine Literature and Culture, ed. T. Antonopoulou, S. Kotzabassi, M. Loukaki, Berlin-New York 2015 [= BArchiv, 29], p. 195-210; A. Konstantakopoulou, $\Lambda \alpha o i ́, \varphi v \lambda \alpha i ́, \gamma \lambda \omega \sigma \sigma \alpha \iota . \Delta \iota \alpha \kappa \rho i ́ \sigma \varepsilon l \varsigma \sigma \tau \alpha$ B $\alpha \lambda$ -

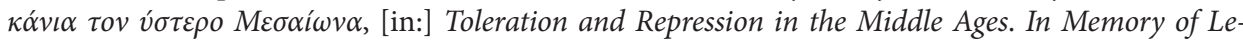

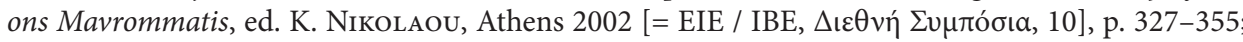
P. SChreIner, Bilinguismus, Bilateralität und Digraphie in Byzanz, [in:] Historische Mehrsprachigkeit, ed. D. Boschung, C.M. Riehl, Aachen 2011 [= ZSM.S, 4], p. 125-141; IDEM, Ethnische Invektiven in der spätbyzantinischen Händlerwelt. Zum anonymen Poem im Marc. gr. XI, 6 aus dem dritten oder vierten Jahrzehnt des 14. Jahrhunderts, ЗРВИ 50, 1-2, 2013 (= Mélanges Ljubomir Maksimović, ed. B. Krsmanović, S. Pirivatrić, vol. II), p. 763-778.

${ }^{21}$ For the significance of religion in the context of shaping of Byzantine political identity, see currently the comprehensive collection edited by G. DunN and W. MAYER, Christians Shaping Identity from the Roman Empire to Byzantium. Studies Inspired by Pauline Allen, Leiden 2015 [= VC.S, 132], in particular the contributions from D.C. SIM, Jews, Gentiles and Ethnic Identity in the Gospel of Matthew, [in:] Christians Shaping Identity..., p. 25-47, and from R. Sсотт, The Treatment of Ecu- 
identity: patris, polis, politeuma, kome, chorion; klima, epeiros, oikoumene ${ }^{22}$, phenomena which are deeply rooted in human consciousness.

This paper does not deal with space, religion and language, which were discussed in earlier studies, but with one further complex dimension, the relationship between identity and time.

\section{Identity and time}

At first glance, time and temporality are not so obviously related to identity, though they are immanent in human consciousness and as phenomena not imaginable without beginning and $\mathrm{end}^{23}$. Characteristically, William Butler Yeats says at the beginning of his famous Vision:

I think if I could be given a month of Antiquity and leave to spend it where I chose, I would spend it in Byzantium a little before Justinian opened St. Sophia and closed the Academy of Plato ${ }^{24}$. I think I could find in some little wine shop some philosophical worker in mosaic who could answer all my questions, the supernatural descending nearer to him than to Plotinus even, for the pride of his delicate skill would make what was an instrument of power to princes and clerics, a murderous madness in the mob, show as a lovely flexible presence like that of a perfect human body. ${ }^{25}$

Following him, human beings identify their belonging not only in terms of space, but also in terms of time. Mikhail Bakhtin had an entirely different approach to time: some hundred years ago, he referred to Einstein's Theory of

menical Councils in Byzantine Chronicles, [in:] Christians Shaping Identity..., p. 364-384; furthermore: L.D. RiedeL, Leo VI and the Transformation of Byzantine Christian Identity. Writings of an Unexpected Emperor, Cambridge 2018, and J. Koder, Byzanz - römische Identität, christliche Ideologie und europäische Ausstrahlung, [in:] Katalog zur Ausstellung "Das Goldene Byzanz und der Orient", ed. F. Daim, D. Heher, Schallaburg 2012, p. 27-41.

${ }^{22}$ For space: J. Koder, Space and Identity - Byzantine Conceptions of Geographic Belonging, Opening lecture, [in:] From the Human Body to the Universe. Spatialities of Byzantine Culture, Symposium Uppsala University, 18-21 May 2017 (in print); IDEM, Byzantion wird Konstantinupolis: Anmerkungen zu Ortswahl und Namen, [in:] Constantinople réelle et imaginaire autour de l'oeuvre de Gilbert Dagron, ed. C. Morrisson, J.-P. Sodini (= TM 22, 1), Paris 2018, p. 21-33; IDEM, Anmerkungen zum Awaren-Sgraffito von Sirmium, comm. R. Wedenig, [in:] Lebenswelten zwischen Archäologie und Geschichte. Festschrift für Falko Daim zu seinem 65. Geburtstag, ed. J. Drauschke et al., Mainz 2018 [= MRGZ, 150], p. 733-740.

${ }^{23}$ See: H.U. Gumbrecht, Zeitbegriffe in den Geisteswissenschaften heute, [in:] Akademie im Dialog, X, Vienna 2017, p. 5-13; in general: V. GrumeL, La Chronologie, Paris 1958 [= TEB, 1], p. 161-235. ${ }^{24}$ In 529 or a little later, the emperor Justinian imposed a ban of teaching in the Platonic Academy in Athens; on December 27 $7^{\text {th }}, 537$, he inaugurated the new Saint Sophia (the second building being destroyed by fire during the Nika riot, 532); see: R. ScotT, Justinian's New Age and the Second Coming, [in:] IDEM, Byzantine Chronicles and the Sixth Century, Ashgate 2012, p. 7-8.

${ }^{25}$ W.B. YeATs, A Vision, London 1937, p. 279. 
Relativity and introduced the term chronotope ("time-space") into the theory of literature, in order to express the inseparability of space and time:

The special meaning it [scil. the chronotope] has in relativity theory is not important for our purposes; we are borrowing it for literary criticism almost as a metaphor... What counts for us is the fact that it expresses the inseparability of space and time (time as the fourth dimension of space)... The chronotope as a formally constitutive category determines to a significant degree the image of man in literature as well. The image of man is always intrinsically chronotopic. $^{26}$

As for the topic "time in Byzantium", Paolo Odorico, starting from the peak of the confrontation between Neoplatonism and Christianity in the $6^{\text {th }}$ century, recently made a significant contribution. He studied the influence of four categories of time - cosmic, historical, social, and individual - on the human condition and pointed to the formation of a new class of historiography that focussed on a universal history since the creation of the world (John Malalas, the Chronicon Paschale...): Le temps cosmique est pour les Byzantins fondé sur l'action de Dieu, et de Lui dépend aussi le temps historique, qui ne repose que sur sa volonté. Le temps social de l'Empire s'aligne sur cette base, en rapportant à la dimension théologique [emphasized by JK] toute son organisation ${ }^{27}$. Earlier, Gilbert Dagron analyzed the ecumenic purview of the emperors' political and religious power ${ }^{28}$. In his remarks on the territorial and temporal ecumenicity, he emphasized the latter's importance, which still increased in the $9^{\text {th }}$ and $10^{\text {th }}$ centuries. Relying on these considerations, it is obvious to postulate an inseparability of time and identity, especially collective identity.

The outstanding importance of eschatological time was highlighted by Gerhard Podskalsky and Paul Magdalino. Podskalsky ${ }^{29}$ again emphasized the theological origin of the Byzantine concept of history in the Jewish and Hellenistic tradition

\footnotetext{
${ }^{26}$ M. BAкнtin, Forms of Time and of the Chronotope in the Novel, [in:] The Dialogic Imagination, Austin 1981, p. 84sq.

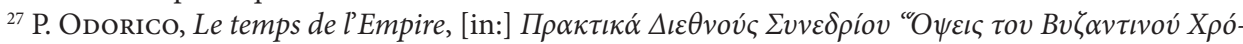
vov", 29-30 Maïov 2015, ed. E.G. Sarante, A. Dellaporta, T. Kollyropoulou, Athens 2018, p. 30-41 (with rich bibliography), the quotation from p. 40; see also: the graph on p. 31.

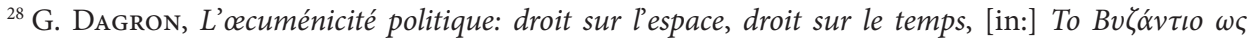

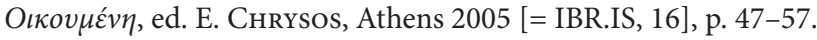

${ }^{29}$ G. Podskalsky, Représentation du temps dans l'eschatologie impériale byzantine, [in:] Le temps chrétien de la fin de l'Antiquité au Moyen Âge - III ${ }^{e}-X I I I^{e}$ siècle (Colloque int. du CNRS 604), ed. J.-M. Leroux, Paris 1984, p. 439-450. Some years later Podskalsky (Ruhestand oder Vollendung? Zur Symbolik des achten Tages in der griechisch-byzantinischen Theologie, [in:] Fest und Alltag in Byzanz, ed. G. PrinzING, Munich 1990, p. 157-166, 216-219), studied the discussion of the Church fathers on the biblical symbolism of the number Eight, which replaces Seven, and the transition to the eighth aion, to the eighth-days-system on the occasion of Christ's resurrection. For this topic, see also: A. Sharf, The Eighth Day of the Week, [in:] Kathegetria. Essays Presented to Joan Hussey for her $80^{\text {th }}$ Birthday, ed. J. Chrysostomides, Camberley 1988, p. 27-50.
} 
and identified two types of imperial eschatology, the political and the religious, resulting in the perpetuation of the millennial reign. Magdalino ${ }^{30}$ took the chronological scheme of the cosmic week, which originated in the era of the world and dominated the thought of Byzantine authors, as an occasion to point out their concentration on the fate of the Byzantine empire and its capital Constantinople, when they express their eschatological expectations.

Only recently, Ilias Anagnostakis ${ }^{31}$ discussed the relationship between time

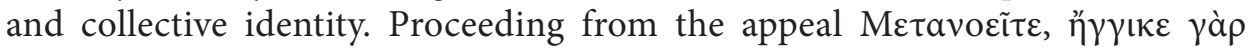

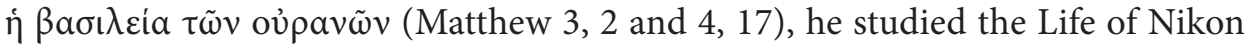
Metanoeite not only as an element of the narrative in the saint's life, but also "as an element of the saint's identity and as the reflection of an eschatological age", and "as the regulatory element in the religious identity of a community", thus emphasizing the importance of time for collective identity.

$$
* * *
$$

For a nearer analysis of the relationship between time and identity, the meanings of key words like aion, kairos and chronos, and the relationships among them are helpful ${ }^{32}$. In spite of their versatile use in Patristic and Byzantine texts and their ambiguity, a closer examination of these three terms opens the opportunity for differentiated interpretations (and translations), which comply with the development of meanings in post-classical Greek and offer efficient links to identity. Not surprising, many of these meanings are strongly influenced by the Bible; the following four passages in the Septuagint and the New Testament ${ }^{33}$ may underpin this observation:

Ecclesiastes 3, 1-2, 11, 14: For every thing there is a chronos (time) and for every matter under heaven a kairos (right time), a kairos to give birth and a kairos to die, a kairos to plant and a kairos to harvest the planted... He made everything good in its kairos; and he has given the aion (eternity) in their heart, but mankind should not comprehend what God had created, from beginning to the end..., I understood that whatever God had done, lasts for the aion; there is no adding to it, and no taking away from it.

\footnotetext{
${ }^{30}$ P. Magdalino, The End of Time in Byzantium, [in:] Endzeiten. Eschatologie in den monotheistischen Weltreligionen, ed. W. Brandes, F. Schmieder, Berlin 2008, p. 119-133.

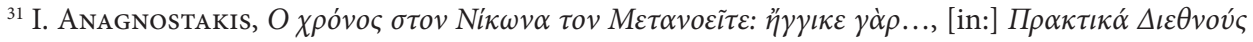

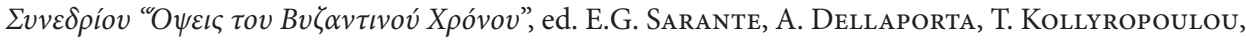
Athens 2018, see here p. 213: ...

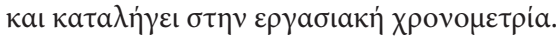

${ }^{32}$ In the cases of eniautos and etos (not in G.H.W. Lampe, A Patristic Greek Lexicon, Oxford 1961 and E. Trapp et al., Lexikon zur byzantinischen Literatur, vol. I-II, Vienna 2001-2017), both correspond in principle ( $L S J$, col. 576b-577a, and 704a) to "year", the former emphasizing the duration of the year (see: e.g., Pseudo-Ioannes Zonaras, Lexikon, epsilon 717), the second the unit of time (I am grateful to the anonymous reader for this clarification).

${ }^{33}$ English translations borrowed (and adapted) from: https://www.biblestudytools.com/esv/ [4 I 2019].
} 
Sophia Salomonis 7, 17-19: For he himself gave me an unerring knowledge of the things that exist, to know the constitution of the world and the activity of the elements, the arche (beginning) and telos (end) and middle of chronoi (times), the alterations of the solstices and the changes of the kairoi (seasons), the cycles of the eniautos (year) and the constellations of the stars...

Titus 1, 1-3: Paul, a servant of God and an apostle of Jesus Christ, for the sake of the faith of God's elect and their knowledge of the truth, which accords with godliness, in hope of aionios (eternal) life, which God, who never lies, promised a long chronos (time) ago and the idioi kairoi (proper times) manifested in his word through the preaching with which I have been entrusted by the command of God our Savior...

Luke 18, 29-30: Truly, I say to you, there is no one who has left house or wife or brothers or parents or children, for the sake of the kingdom of God, who will not receive many times more in this kairos (time), and in the aion (age) to come the aionios zoe (eternal life) ${ }^{34}$.

The framework of meanings of aion, kairos and chronos is confirmed by these and other ${ }^{35}$ passages in the New Testament. For a more differentiated understanding of the terms during the Byzantine period, I am quoting some characteristic examples from the large number of relevant Patristic texts, beginning with the definitions by Pseudo-Zonaras and continuing with quotations from other sources. Pseudo-Zonaras defines aion: "the time or what is coextensive in the heavens, like a temporal movement or distance" ${ }^{36}$; kairos: "suitable time for work" ${ }^{37}$; and kata kairon: "in the convenient and appointed time, so the apostle: He [Christ] died at the appointed time for the wicked"38; chronos: "movement and course of the sun in a proportioned motion; or the coextensive with the substance of the world distance, in which every movement is measured, be it of the stars or living being or whatever is moved" 39 .

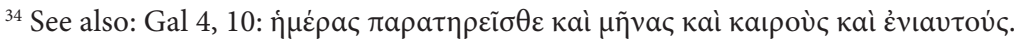

${ }^{35}$ E.g. Gal 6, 7-10: Do not be deceived: God is not mocked, for whatever one sows, that will he also reap. For the one who sows to his own flesh will from the flesh reap corruption, but the one who sows to the Spirit will from the Spirit reap eternal life ( $\zeta \omega \eta \dot{v}$ ai $\omega \dot{v} v \mathrm{ov})$. And let us not grow weary of doing good, for

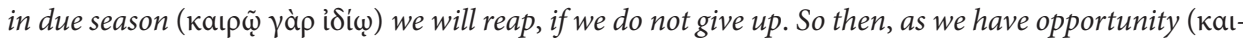
póv), let us do good to everyone. Act 1, 6-8: So when they had come together, they asked him, Lord, will

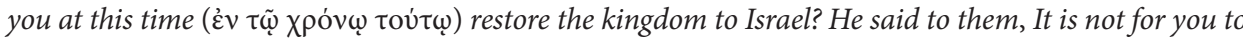

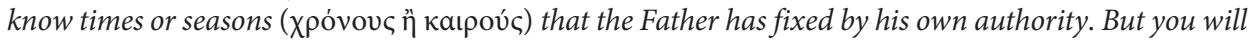
receive power when the Holy Spirit has come upon you, and you will be my witnesses in Jerusalem and in all Judea and Samaria, and to the end of the earth.

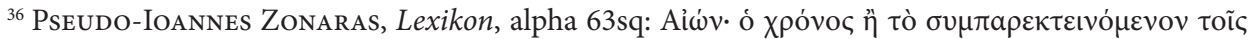

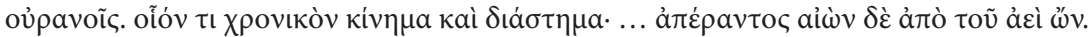

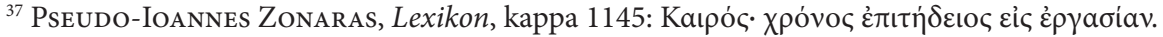

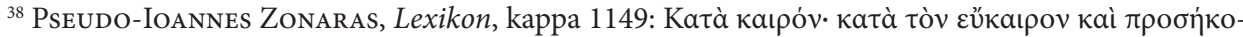

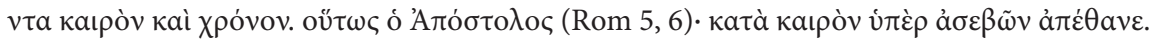

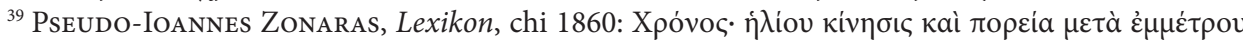

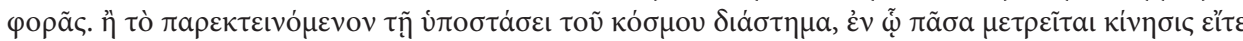

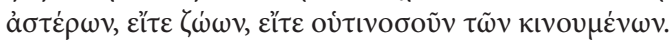




\section{kairos $^{40} /$ chronos $^{41}$}

Pseudo-Galenus, in Peri chymon, draws a remarkable parallel in the following comparison: "What in the universe (kosmos) is an element (stoicheion), is in human beings a humour (chymos), even as in the year (chronos) a season (kairos), not having complete identity (tautotes) or likeness (homoiotes)... the seasons of the year being spring, summer, winter and autumn"42.

In the early $9^{\text {th }}$ century, two authors explain the difference of chronos and kairos for their contemporaries. George Choiroboscus answers the question "How differ kairos and chronos?" as follows: "kairos is the measured arrival of days, chronos the extent of many kairoi and days" ${ }^{43}$. Michael Syncellus explains that "chronos is more general and comprehensive than kairos; chronos encompasses kairos, but kairos does not encompass chronos" ${ }^{\prime 4}$. The term chronos stands in the tradition of the Antiquity; it is formulaically linked with trochos and tyche, this often in ecclesiastical texts ${ }^{45}$,

\footnotetext{
${ }^{40}$ kaıpós (often contrasted to aî́w): due measure, proportion, fitness, exact or critical or convenient time, season, opportunity, period (LSJ, col. 859b-860a); fit, right, proper time, opportunity, present age, age to come, ages of history, and time compared with eternity (G.H.W. LAMPE, A Patristic..., col. 693b); year (E. Trapp et al., Lexikon zur..., col. 734b).

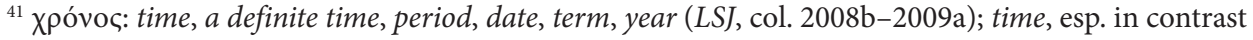
to kairos and to aion, (divine) timelessness, eternity (of Son or Word), occasion and year (G.H.W. LAMPE, A Patristic..., col. 1534b).

${ }^{42}$ Pseudo-Galenus, De humoribus, 19.485sq, [in:] Claudii Galeni opera omnia, vol. XIX, ed.

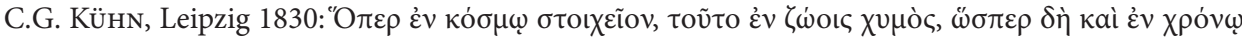

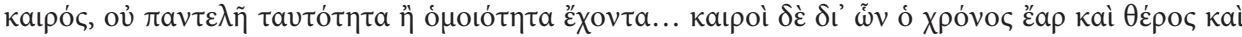

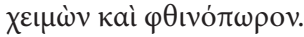

${ }^{43}$ Georgius Choiroboscus, Epimerismi in Psalmos, vol. III, ed. T. Gaisford, Oxford 1842, p. 47:

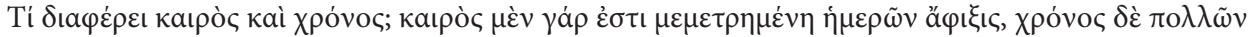

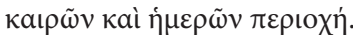

${ }^{44}$ Michael Syncellus, Le traité de la construction de la phrase de Michel le Syncelle de Jérusalem,

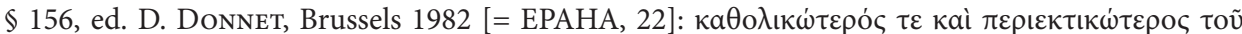

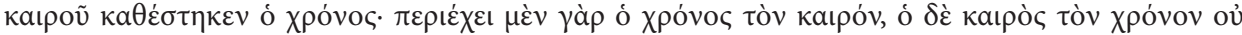

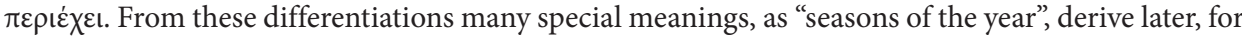

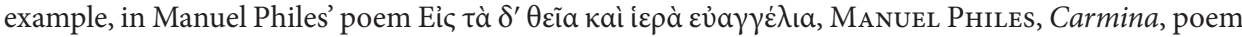
39, vol. I-II, ed. E. Miller, Paris 1855-1857):
}

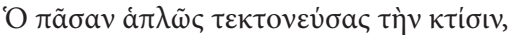

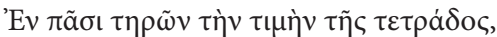

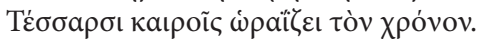

${ }^{45}$ IsIdorus Pelusiota, Epistulae de interpretatione divinae scripturae, [in:] PG, vol. LXXVIII,

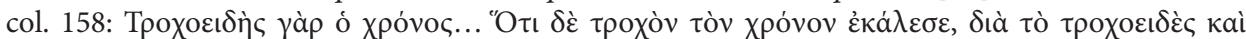

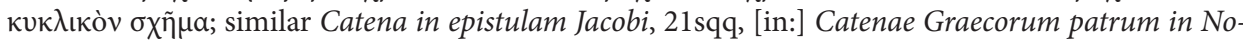
vum Testamentum, vol. VIII, ed. J.A. Cramer, Oxford 1840; Gregorius Agrigentinus, Commentarius in Ecclesiasten, 1.13, [in:] Pseudo-Gregorii Agrigentini seu Pseudo-Gregorii Nysseni commentarius

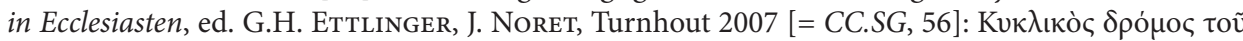

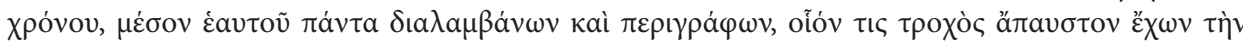

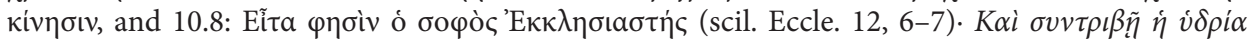


but also among non-theological authors ${ }^{46}$, whereas the term kairos is used only as an exception in this context ${ }^{47}$.

\section{kairos / aion $^{48}$}

As early as the break between the $4^{\text {th }}$ and $5^{\text {th }}$ centuries, the relationship between kairos and aion is explained by John Chrysostomus: "Short is the present kairos in relation to the interminable aiones" ${ }^{49}$. In another homily, he refers to Paul's letter to the Romans: “... and we must leave off from indifference. For deliverance is nearer now than we believed. Do you see, how he draws their attention already to the resurrection? As the chronos goes on, he says, the kairos of this life will be consumed and that of the future aion comes nearer" ${ }^{50}$. One generation earlier, Basil of Caesarea makes a clear distinction between the short kairos of this life and the eternity of the aion: "The present kairos is for repentance and forgiving of sins; but in the future aion comes the just judgement of retribution" ${ }^{51}$.

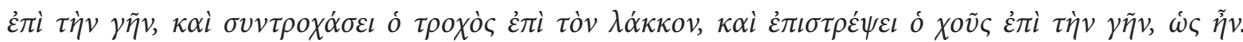

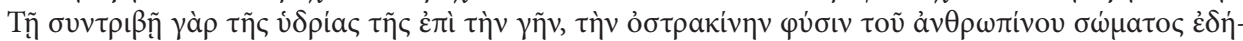

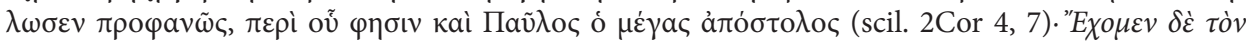

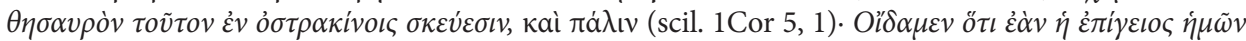

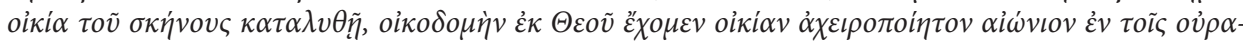

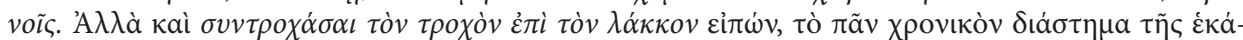

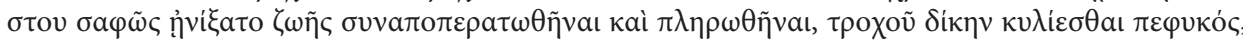

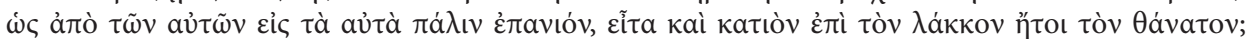

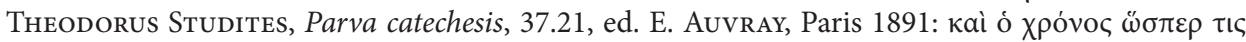

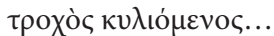

${ }^{46}$ Examples: Georgius Choiroboscus, Prolegomena et scholia in Theodosii Alexandrini canones de flexion verborum, [in:] Grammatici Graeci, vol. IV.2, ed. A. HILGARD, Leipzig 1894, p. 11; TheOdorus

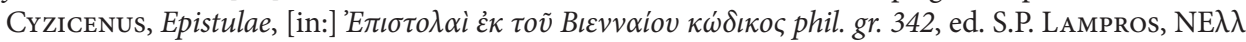

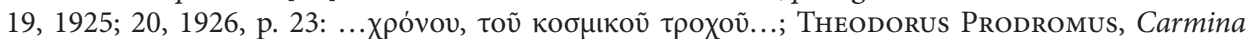
historica, Poem 45.365, [in:] Theodoros Prodromos, Historische Gedichte, ed. W. Hörandner, Vienna

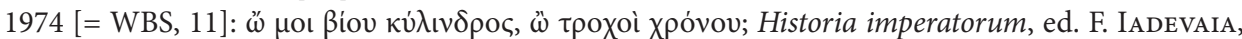

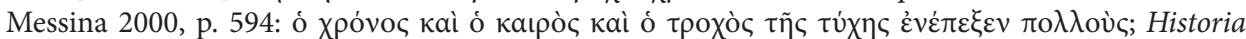
Alexandri Magni, 57.16, [in:] Ps.-Kallisthenes. Zwei mittelgriechische Prosa-Fassungen des Alexanderromans, vol. I-II, ed. V.L. Konstantinopulos, A.C. Lolos, Meisenheim am Glan 1983 [= BKP, 141].

${ }^{47}$ Georgius Monachus, Chronicon breve, [in:] PG, vol. XC, col. 1205, 1228, 1240.

${ }^{48}$ aìuv: period of existence, lifetime, life, age, generation, destiny, long space of time, age, space of time clearly defined and marked out, epoch, age, epoch, age, the ages, i.e. eternity (LSJ, col. 45b); age, aeon, eternity, time, long but definite period, but also period(s) of indefinite duration (G.H.W. LAMPE, A Pa-

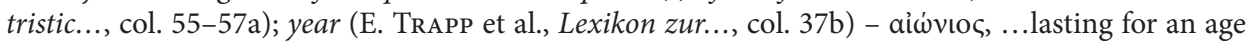

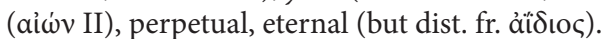

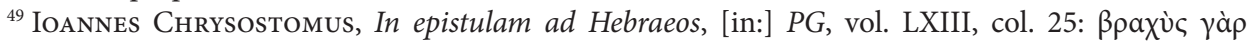

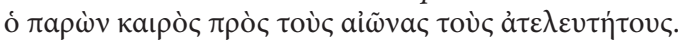

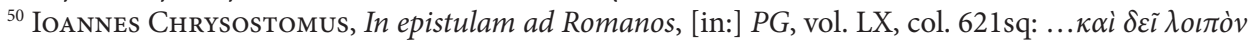

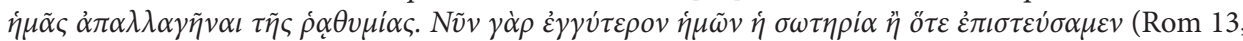

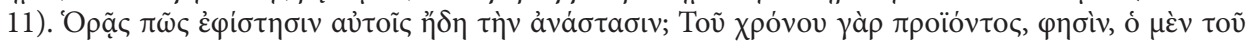

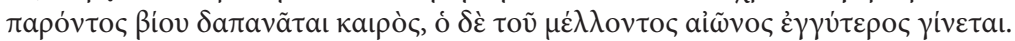

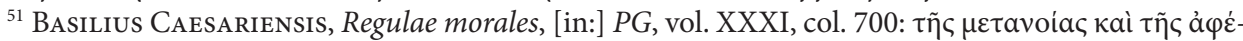

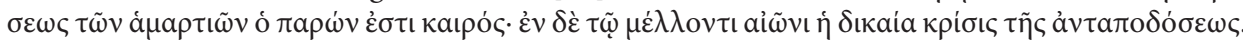




\section{aion / chronos}

The relationship between aion and chronos was subject to the continuous development of both term's meanings. In the majority of cases, it may be found in theological contexts, once already in an ancient tragedy ${ }^{52}$. In the Septuagint, with some

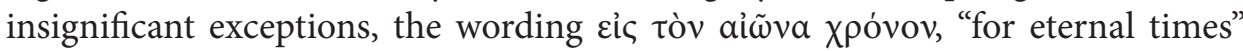
(adjectival use of $\left.\alpha^{i} \omega \omega v\right)^{53}$ dominates, and this wording was predominant in the patristic literature until the $5^{\text {th }}$ century $y^{54}$.

The development towards a separate interpretation of the two terms began obviously from the $5^{\text {th }} / 6^{\text {th }}$ centuries, in particular in the discussion of the meaning of the aïdiótes ("everlastingness") 55 . A representative selection from the large number of authors should begin with Pseudo-Dionysius Areopagita; he postulates in De divinis nominibus:

It is necessary, I believe, to be informed about the nature not only of time (chronos), but also of eternity (aion) by the savants,

and he continues with an explanation, from which the main passage reads as follows:

... He [scil. Gregory of Nyssa] calls time, what by generation and destruction and alteration occasionally acts differently. Therefore, the theology teaches that we already here, bound in time, participate in eternity, whenever we are suitable for the eternal and always such existing eternity... (Therefore, we should) send hymns to God as eternity and time, as creator of all time and eternity and as 'ancient of days', because he is before time and above time and changing 'periods (kairoi) and times (chronoi)' and again existing before eternities, being before eternity and above eternity, and his kingdom is the kingdom of all eternities. ${ }^{56}$

\footnotetext{
${ }^{52}$ By the chorus in Aeschylus, Septem contra Thebas, v. 219sq, [in:] Aeschyli Septem Quae Super-

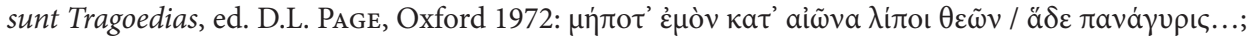
see: the explanation in Scholia Graeca in Aeschylum quae exstant omnia, hypothesis-epigram-scho-

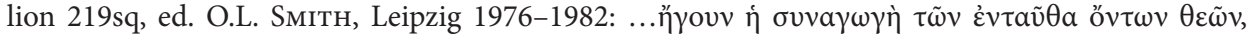

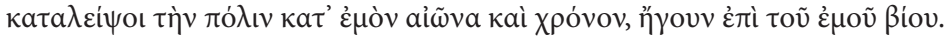

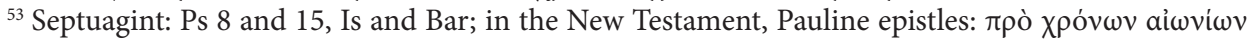
and similar.

${ }^{54}$ Eusebios of Caesarea, Basil of Caesarea, Didymus the Blind, Ephrem the Syrian, Theodoret of Cyrrhus and Cyril of Alexandria. A later example is the Second Council of Nicaea.

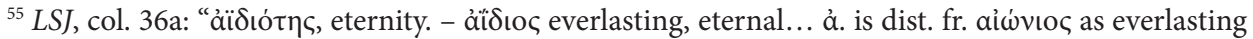
from timeless, but dist. fr. ả $\varepsilon^{\prime} \zeta \omega \circ \zeta$ as eternal (without beginning or end) from ever-living".

${ }^{56}$ Pseudo-Dionysius Areopagita, De divinis nominibus, ed. B.R. Suchla, Berlin 1990 [= PTS, 33],

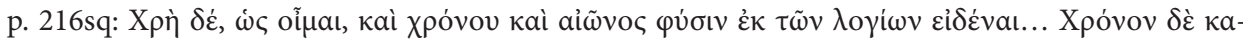
$\lambda \varepsilon \tilde{i}$ (possibly Gregorius Nyssenus, In sanctum Pascha, [in:] Gregorii Nysseni opera, vol. IX.1, ed.

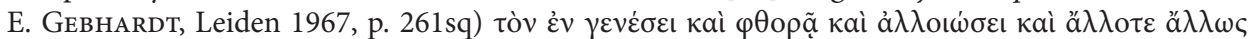

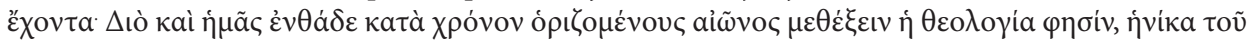

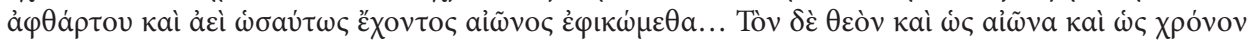

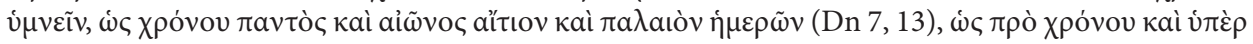

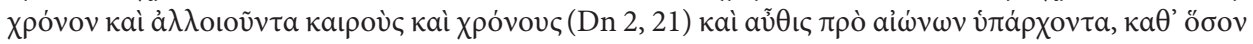

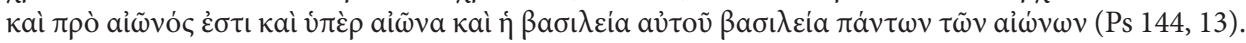




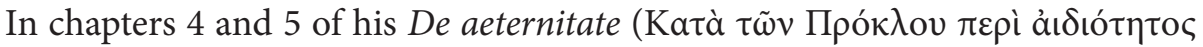

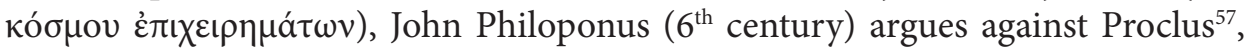
and he offers a concise definition: "Eternity (aion) existed when time (chronos) did not exist, and eternity will exist when time will not exist"58. The Doctrina Patrum ( $7^{\text {th }}-8^{\text {th }}$ centuries) says in a similar manner: "Eternity (aion) is timeless time (chronos achronos) and endless end (peras aperanton) $)^{59}$. Finally, John of Damascus $\left(7 / 8^{\text {th }}\right.$ century) states: "What for those under the time (chronos) is the time, is for those in the everlasting (aïdia) the eternity (aion)" 60 .

Most of the authors after the turn of the millenium remained more or less in the paths of their predecessors, so, for example, John Italus $\left(11^{\text {th }} \text { century }\right)^{61}$ and Gregory Palamas ${ }^{62}$. I should also mention John Cyparissiotes, who quotes De divinis nominibus, book 10 of Dionysius Areopagita ${ }^{63}$, and Gennadius Scholarius, who authored an epitome of the first part of Thomas Aquinas' Summa Theologiae ${ }^{64}$.

The personality who deals with the relationship between aion and chronos several times is Michael Psellus ( $11^{\text {th }}$ century) - not only in the Opusculum logicum $4^{65}$ and in the Theological Treatises 41, 88 and 105, but especially in his Theological Treatise 32, which is entirely dedicated to the topic "About eternity" (Peri aionos) ${ }^{66}$ :

\footnotetext{
${ }^{57}$ Ioannes Philoponus, De aeternitate mundi contra Proclum, ed. H. Rabe, Leipzig 1899 (cetera:

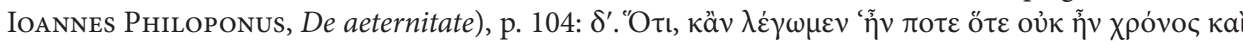

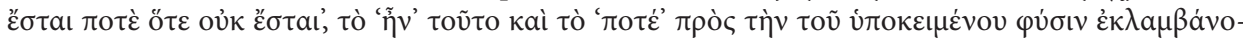

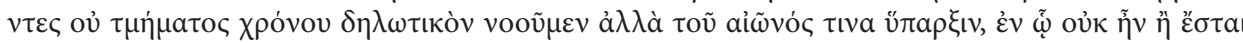

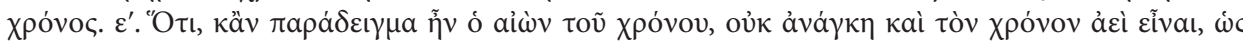
ó aỉùv ả $\varepsilon \dot{~ \varepsilon ́ \sigma \tau t v . ~}$

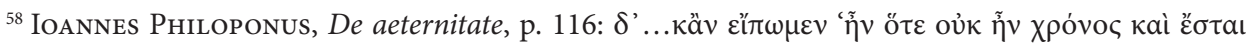

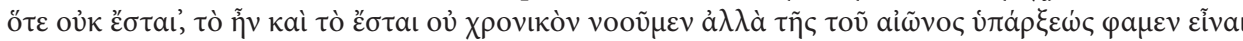

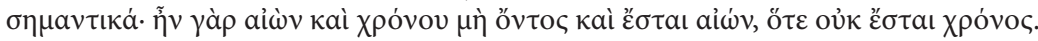

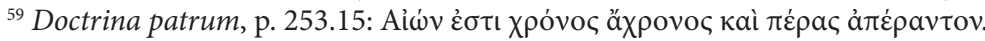

${ }^{60}$ Ioannes Damascenus, Expositio fidei, [in:] Die Schriften des Johannes..., vol. II, Berlin 1973

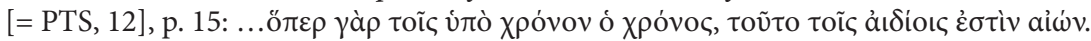

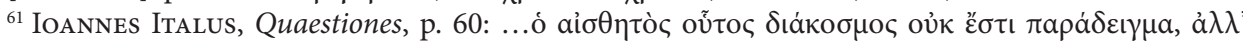

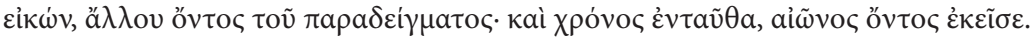

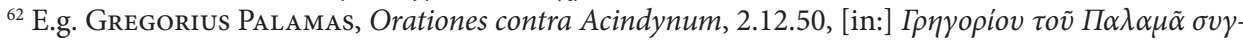
$\gamma \rho \alpha ́ \mu \mu \alpha \tau \alpha$, vol. III, ed. L. Kontogiannes, B. Phanourgakes, Thessalonica 1970.

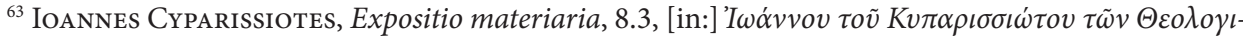
$\kappa \tilde{\omega} v{ }^{\prime} P \dot{\eta} \sigma \varepsilon \omega v \Sigma \tau o \iota \chi \varepsilon \iota \omega ́ \delta \eta \varsigma^{\prime} E \kappa \theta \varepsilon \sigma \iota \varsigma$, ed. B.L. Dentakes, Athens 1982 [= HФM, 5].

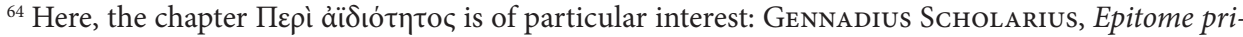
mae partis Summae theologice Thomae Aquinae, Treatise 1.10, [in:] Oeuvres complètes de Georges (Gennadios) Scholarios, vol. V, ed. M. Jugie, L. Petit, X.A. Siderides, Paris 1931.

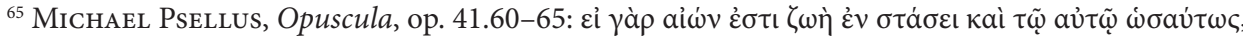

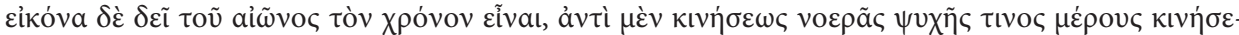

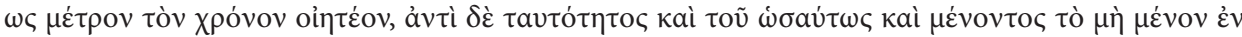

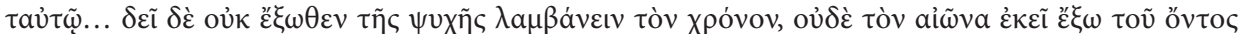

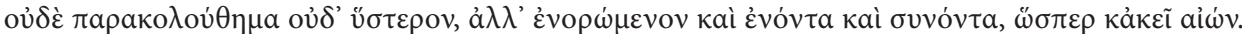
${ }^{66}$ Michael Psellus, Theologica, op. 32, Пepi aĩuvos (etiam: De omnifaria doctrina, Appendix 2, Пepì aíũvoc.
} 
Understand time (chronos) as an image of eternity (aion). If so, the reasoning by conversion says: agree that eternity is an example for the time... Such is eternity; time is a product of it, left behind by the father's state. It was born in order to come to an end... We participated in a small share of the nature of time. The soul... is placed between eternity and time... Its substance is eternal, but its energy is temporal... Also the harmonious concordance of time and eternity leads me to this, as the opposites - correlating with each other - coalesced ${ }^{67}$

The individualization and personalization of temporality can be verified by the combination of time-related terms with the possessive pronouns emos or (collectively) hemeteros. A biblical starting point seems to be the passage in the Gospel of John: Jesus said to them, My time has not yet come, but your time is always here... Go to the festival yourselves. I am not going to this festival, for my time has not yet fully come ${ }^{68}$, which was commented on in the Catena in Ioannem ${ }^{69}$ and from many Church fathers (Athanasius of Alexandria, Basil of Caesarea, Cyril of Alexandria, John Chrysostomus, Nilus of Ancyra and Socrates Scholasticus ${ }^{70}$ ).

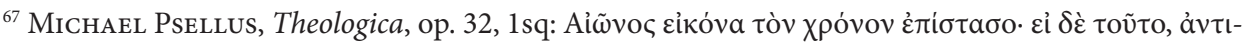

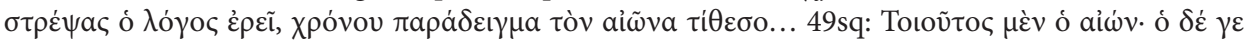

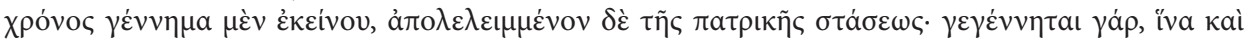

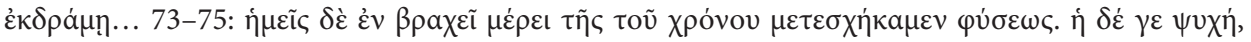

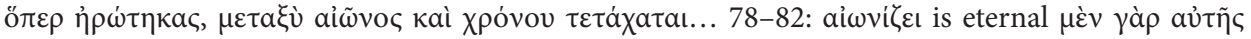

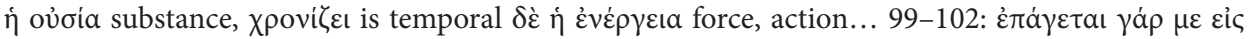

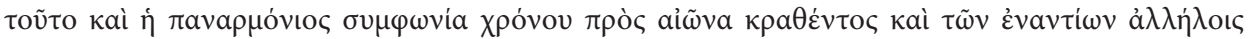

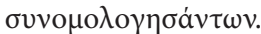

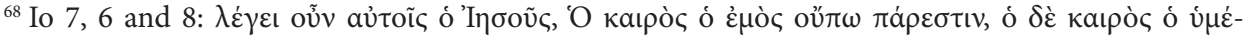

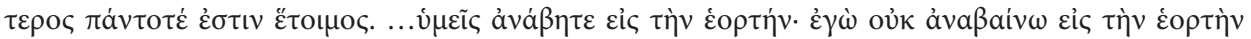

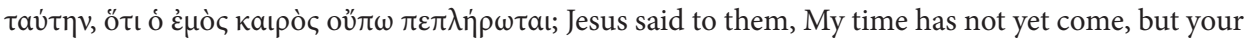
time is always here. - See also: Nonnus' Paraphrasis sancti evangelii Ioannei, VII, 23-25, 32-35, ed. A. SCHEINDLER, Leipzig 1881:
}

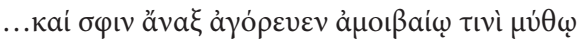

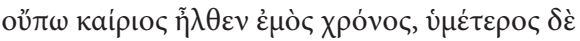

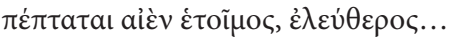

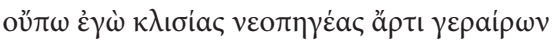

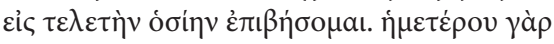

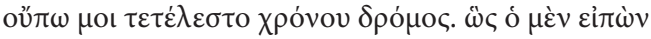

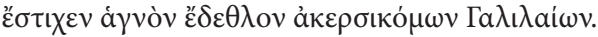

${ }^{69}$ Catena in Ioannem, 261.6 and 30sq, [in:] Catenae Graecorum patrum..., vol. II, Oxford 1841:

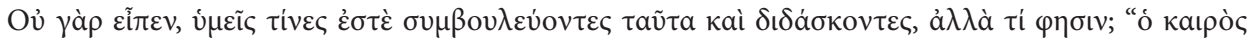

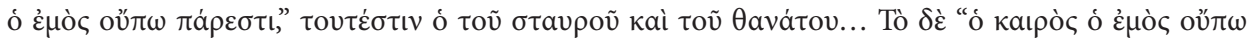

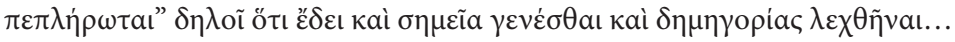

${ }^{70}$ Basilius Caesariensis, Regulae morales, [in:] PG, vol. XXXI, col. 797, 800; Cyrillus AlexandriNus, Commentarii in Joannem, [in:] Sancti patris nostri Cyrilli archiepiscopi Alexandrini in D. Joannis evangelium, vol. I, ed. P.E. Pusey, Oxford 1872, p. 400, 584, 587; IoANnes Chrysostomus, In Ioannem, [in:] PG, vol. LIX, col. 271; Nilus Ancyrenus, Epistulae, III, Ep. XLIII, [in:] PG, vol. LXXIX. For Athanasius of Alexandria and Socrates Scholasticus see below. 
Athanasius of Alexandria ${ }^{71}$ and Socrates Scholasticus ${ }^{72}$ extended the interpretation of Io 7 in referring additionally to Mt 26, 45: Then he came to the disciples and said to them, Are you still sleeping and taking your rest? See, the hour is at hand, and the Son of Man is betrayed into the hands of sinners ${ }^{73}$, and to the marriage in Cana, Io 2, 3-5: When the wine gave out, the mother of Jesus said to him, They have no wine. And Jesus said to her, Woman, what concern is that to you and to me? My hour has not yet come. His mother said to the servants, Do whatever he tells you ${ }^{74}$. Thus both authors indicate the general significance of kairos (and even hora, "time of day"75) as the proper or suitable time in human life.

However, a reference to the present time of the respective authors is only implied or hinted at in these texts. The decisive additional step came from the following authors, who equated the kairos with their individual lifetime or (collectively) with the historical period, in which they and their contemporaries existed: Athanasius of Alexandria critised his opponents, the followers of Arius, who "in our time" by challenging the right faith, do not support the truth, and he compares them with a group of disciples, who did not accept the content of Jesus' teaching on the shore of the Sea of Galilee and in the synagogue at Capernaum (Io 6) ${ }^{76}$. John Chrysostomos appealed to his contemporaries in his $4^{\text {th }}$ homily on the First Letter to the Thessalonians: Ours is the time! Let us use it for what is necessary! Let us cut off the ropes of the sins! Before we pass away, let us judge ourselves!

\footnotetext{
${ }^{71}$ Athanasius, Apologia de fuga sua, col. 13, [in:] Athanase d'Alexandrie. Apologie à l'empereur

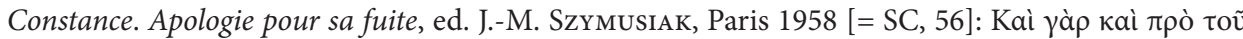

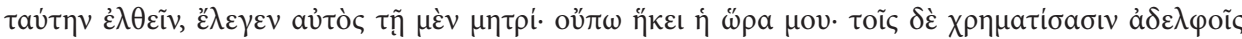

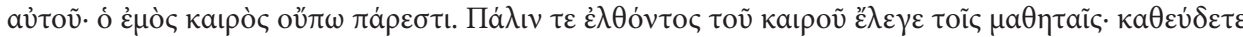

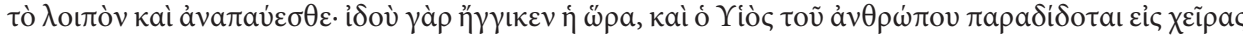
$\dot{\alpha} \mu \alpha \rho \tau \omega \lambda \tilde{\omega} v \ldots$

${ }^{72}$ Socrate de Constantinople, Histoire ecclésiastique, III, 8.39-41, vol. I-IV, ed. P. Maraval,

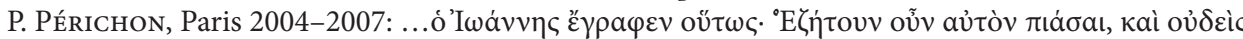

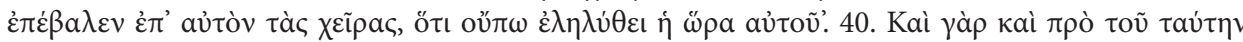

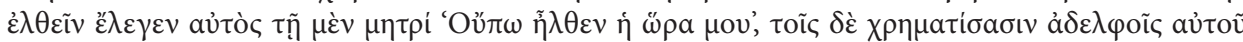

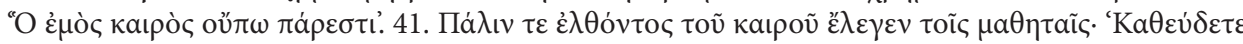

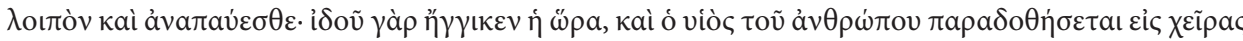

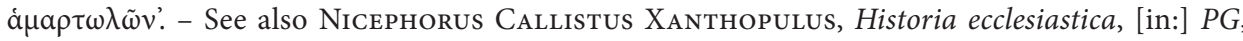
vol. CXLVII, col. 16.

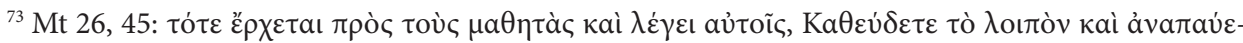

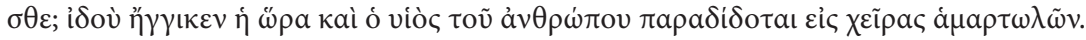

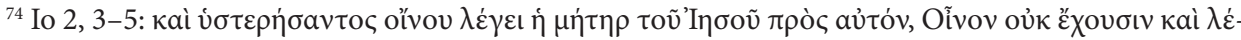

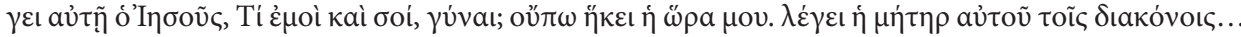
${ }^{75}$ LSJ, col. 2035b-2036a, s.v. $̋ \rho a(C)$, II.1.a.

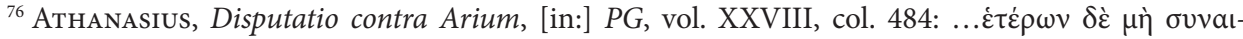

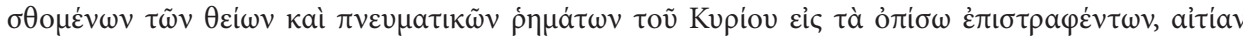

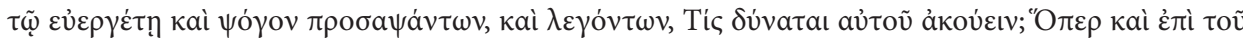

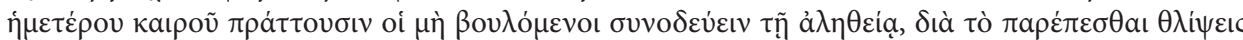

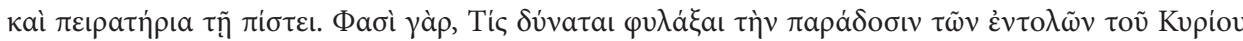
кaì $\tau \tilde{\eta} \varsigma \pi$ i $\sigma \tau \varepsilon \omega \varsigma$;
} 
Do not let the sun go down on your anger! ${ }^{77}$. Ephrem Syrus prayed to God to send to him his grace and to unravel his thoughts, because the distractions and cares during the present time (proskairos kairos) kept him away from God's eternal benefits ${ }^{78}$. Finally, at the end of Byzantium, Gennadius Scholarius lamented "our discord", in comparing it with the mentality of "preparedness" in the times of the apostle Paul ${ }^{79}$.

To sum up the evidence, which results from the quoted sources and the mentioned studies: Time cannot be unlimited and infinite, because for human beings it is unimaginable without beginning and end. Time has to be structured in the dimensions of the past, present and future (and this for different cultures in different ways). The sources allow us to conclude that from the varieties of time (which were identified in the above mentioned bibliography), eschatological (cosmic) time dominated the thinking of the homo byzantinus in relation to individual and collective identity, whereas the historical dimension was rather limited to authors of a small educated class.

\section{Bibliography}

\section{Primary Sources}

Aeschylus, Septem contra Thebas, [in:] Aeschyli Septem Quae Supersunt Tragoedias, ed. D.L. PAge, Oxford 1972, p. 45-87.

Athanasius, Apologia de fuga sua, [in:] Athanase d'Alexandrie. Apologie à l'empereur Constance. Apologie pour sa fuite, ed. J.-M. Szymusiak, Paris 1958 [= Sources chrétiennes, 56], p. 133-167.

\footnotetext{
${ }^{77}$ IoAnnes Chrysostomus, In epistulam I ad Thessalonicenses, hom. IV (on 1Thess 3, 5-8), [in:] PG,

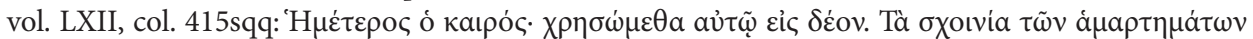

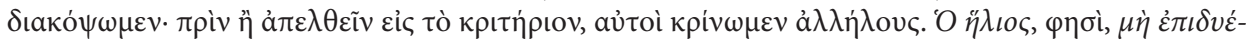
$\tau \omega \dot{\varepsilon} \pi i \dot{i} \tilde{\omega} \pi \alpha \rho o \rho \gamma \iota \sigma \mu \tilde{\omega} \dot{v} \mu \tilde{\omega} v$. (Eph 4, 26).

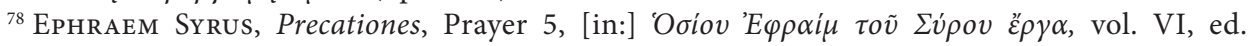

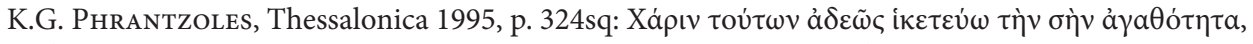

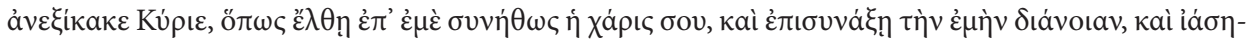

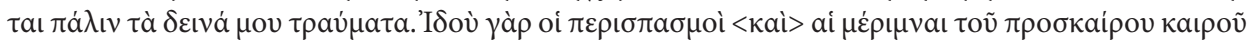

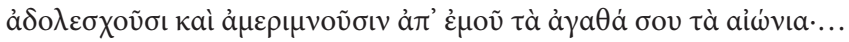

${ }^{79}$ Gennadius Scholarius, Apologia de silentio ad Theodorum Branam, [in:] Oeuvres complètes...,

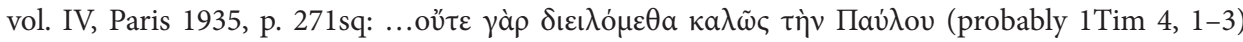

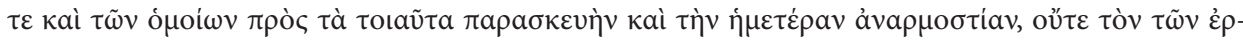

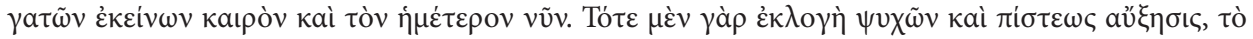

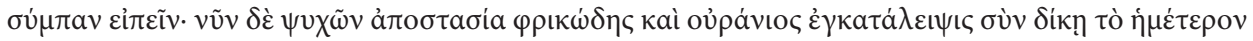

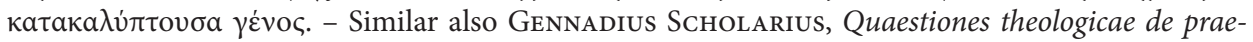

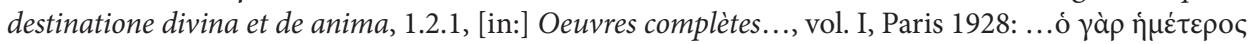

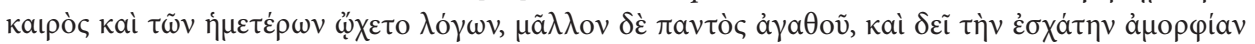

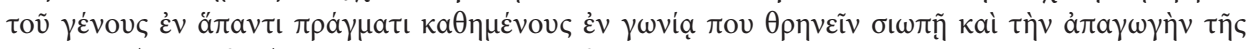

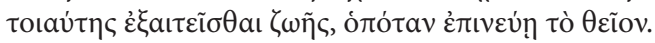


Athanasius, Disputatio contra Arium, [in:] Patrologiae cursus completus, Series graeca, vol. XXVIII, ed. J.-P. Migne, Paris 1857, col. 440-501.

Basilius Caesariensis, Regulae morales, [in:] Patrologiae cursus completus, Series graeca, vol. XXXI, ed. J.-P. Migne, Paris 1857, col. 692-869.

Catena in epistulam Jacobi, [in:] Catenae Graecorum patrum in Novum Testamentum, vol. VIII, ed. J.A. Cramer, Oxford 1840, p. 1-40.

Catena in Ioannem, [in:] Catenae Graecorum patrum in Novum Testamentum, vol. II, ed. J.A. CrAMER, Oxford 1841, p. 177-413.

Clemens Alexandrinus, Stromata, [in:] Clemens Alexandrinus, vol. II-III, ed. L. Früchtel, O. StÄhlin, U. Treu, Berlin 1960-1970 [= Die griechischen christlichen Schriftsteller der ersten [drei] Jahrhunderte, 52].

Cyrillus Alexandrinus, Commentarii in Joannem, [in:] Sancti patris nostri Cyrilli archiepiscopi Alexandrini in D. Joannis evangelium, vol. I-III, ed. P.E. PusEY, Oxford 1872.

Damascius, In Parmenidem, [in:] Damascii successoris dubitationes et solutiones, vol. II, ed. C.É. Ruelle, Paris 1899.

Doctrina patrum de incarnatione verbi, ed. F. Dieкамp, Münster 1907.

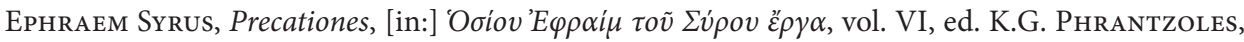
Thessalonica 1995.

Gennadius Scholarius, Apologia de silentio ad Theodorum Branam, [in:] Oeuvres completes de Georges (Gennadios) Scholarios, vol. IV, ed. M. Jugie, L. Petit, X.A. Siderides, Paris 1935, p. $264-274$.

Gennadius Scholarius, Epitome primae partis Summae theologice Thomae Aquinae, [in:] Oeuvres complètes de Georges (Gennadios) Scholarios, vol. V, ed. M. Jugie, L. Petit, X.A. Siderides, Paris 1931, p. 1-338.

Gennadius Scholarius, Quaestiones theologicae de praedestinatione divina et de anima, [in:] Oeuvres complètes de Georges (Gennadios) Scholarios, vol. I, ed. M. Jugie, L. Petit, X.A. Siderides, Paris 1928 , p. 390-539.

Georgius Choiroboscus, Epimerismi in Psalmos, vol. III, ed. T. Gaisford, Oxford 1842, p. 1-192.

Georgius Chогововcus, Prolegomena et scholia in Theodosii Alexandrini canones de flexion verborum, [in:] Grammatici Graeci, vol. IV.2, ed. A. Hilgard, Leipzig 1894.

Georgius Chortatzes, 'E $\rho \omega \varphi$ i $\lambda \eta$, ed. S. Alexiou, M. Aposkiti, Athens 1988.

Georgius Monachus, Chronicon breve, [in:] Patrologiae cursus completus, Series graeca, vol. CX, ed. J.-P. Migne, Paris 1863, col. 41-1260.

Gregorius Agrigentinus, Commentarius in Ecclesiasten, [in:] Pseudo-Gregorii Agrigentini seu Pseudo-Gregorii Nysseni commentarius in Ecclesiasten, ed. G.H. EtTLINGER, J. Noret, Turnhout 2007 [= Corpus christianorum, Series graeca, 56].

Gregorius Nyssenus, In sanctum Pascha, [in:] Gregorii Nysseni opera, vol. IX.1, ed. E. Gebhardt, Leiden 1967, p. 245-270.

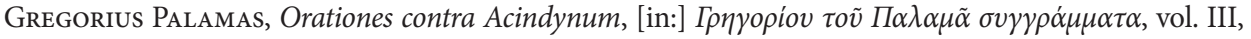
ed. L. Kontogiannes, B. Phanourgakes, Thessalonica 1970, p. 39-506.

Historia Alexandri Magni, [in:] Ps.-Kallisthenes. Zwei mittelgriechische Prosa-Fassungen des Alexanderromans, vol. I-II, ed. V.L. Konstantinopulos, A.C. Lolos, Meisenheim am Glan 1983 [= Beiträge zur klassischen Philologie, 141].

Historia imperatorum, ed. F. IadevaIA, Messina 2000. 
Ionnnes Chrysostomus, In epistulam ad Hebraeos, [in:] Patrologiae cursus completus, Series graeca, vol. LXIII, ed. J.-P. Migne, Paris 1862, col. 9-236.

IoAnnes Chrysostomus, In epistulam ad Romanos, [in:] Patrologiae cursus completus, Series graeca, vol. LX, ed. J.-P. Migne, Paris 1862, col. 391-682.

Ionnnes Chrysostomus, In epistulam I ad Thessalonicenses, [in:] Patrologiae cursus completus, Series graeca, vol. LXII, ed. J.-P. Migne, Paris 1862, col. 391-468.

IoAnnes Chrysostomus, In Ioannem, [in:] Patrologiae cursus completus, Series graeca, vol. LIX, ed. J.-P. Migne, Paris 1862, col. 23-482.

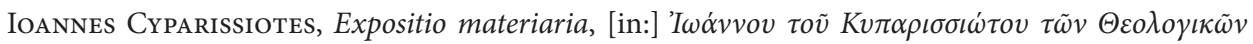

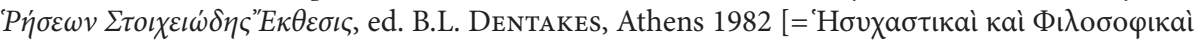
Mèc่tal, 5].

Ioannes Damascenus, Expositio fidei, [in:] Die Schriften des Johannes von Damaskos, vol. II, ed. P.B. Котter Berlin 1973 [= Patristische Texte und Studien, 12].

Ioannes Damascenus, Fragmenta philosophica, [in:] Die Schriften des Johannes von Damaskos, vol. I, ed. P.B. Kотter, Berlin 1969 [= Patristische Texte und Studien, 7], p. 151-173.

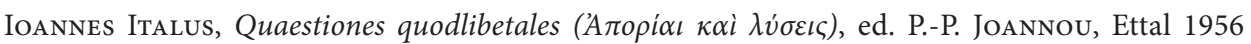
[= Studia Patristica et Byzantina, 4].

Ionnnes Philoponus, De aeternitate mundi contra Proclum, ed. H. Rabe, Leipzig 1899.

Isidorus Pelusiota, Epistulae de interpretatione divinae scripturae, [in:] Patrologiae cursus completus, Series graeca, vol. LXXVIII, ed. J.-P. Migne, Paris 1864, col. 177-1048.

Manuel Philes, Carmina, vol. I-II, ed. E. Miller, Paris 1855-1857.

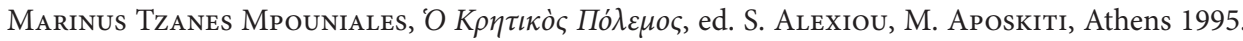

Maximus Homologetes, Relatio motionis, [in:] Patrologiae cursus completus, Series graeca, vol. XC, ed. J.-P. Migne, Paris 1865, col. 109-130.

Michael Psellus, Opuscula philosophica minora, vol. II, Opuscula psychologica, theologica, daemonologica, ed. D.J. O’MeAra, Leipzig 1989.

Michael Psellus, Theologica, vol. I, ed. P. Gautier, Leipzig 1989; vol. II, ed. J.M. Duffy, L.G. WesterinK, Munich-Leipzig 2002.

Michael Syncellus, Le traité de la construction de la phrase de Michel le Syncelle de Jérusalem, ed. D. Donnet, Brussels 1982 [= Études de philologie, d'archéologie et d'histoire anciennes, 22], p. 157-419.

Nicephorus Blemmydes, Epitome logica, [in:] Patrologiae cursus completus, Series graeca, vol. CXLII, ed. J.-P. Migne, Paris 1863, col. 675-1004.

Nicephorus Callistus Xanthopulus, Historia ecclesiastica, [in:] Patrologiae cursus completus, Series graeca, vol. CXLV, col. 560-1332; vol. CXLVI, col. 9-1273; vol. CXLVII, col. 9-448, ed. J.-P. Migne, Paris 1865.

Nilus Ancyrenus, Epistulae, [in:] Patrologiae cursus completus, Series graeca, vol. LXXIX, ed. J.-P. Migne, Paris 1865, col. 82-582.

Nonnus, Paraphrasis sancti evangelii Ioannei, ed. A. ScheIndler, Leipzig 1881.

Pseudo-Dionysius Areopagita, De divinis nominibus, ed. B.R. Suchla, Berlin 1990 [= Patristische Texte und Studien, 33].

Pseudo-Galenus, De humoribus, [in:] Claudii Galeni opera omnia, vol. XIX, ed. C.G. KüHn, Leipzig 1830 , p. $485-496$. 
Pseudo-Ioannes Zonaras, Lexikon, ed. J.A.H. Tittmann, Leipzig 1808.

Scholia Graeca in Aeschylum quae exstant omnia, ed. O.L. Sмiтн, Leipzig 1976-1982.

Socrate de Constantinople, Histoire ecclésiastique, vol. I-IV, ed. P. Maraval, P. Périchon, Paris 2004-2007.

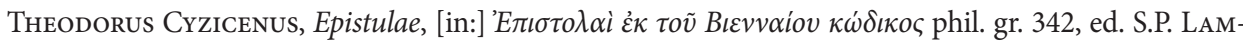

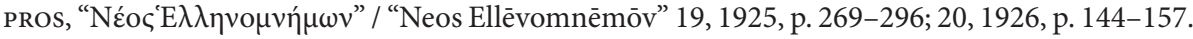

Theodorus Prodromus, Carmina historica, [in:] Theodoros Prodromos, Historische Gedichte, ed. W. Hörandner, Vienna 1974 [= Wiener byzantinistische Studien, 11].

Theodorus Studites, Parva catechesis, ed. E. Auvray, Paris 1891.

\section{Secondary Literature}

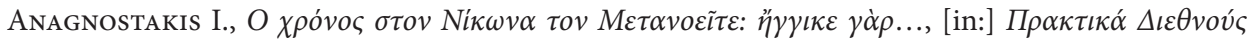

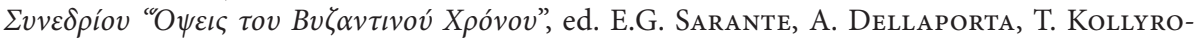
POULOU, Athens 2018, p. 196-218.

Baкhtin M., Forms of Time and of the Chronotope in the Novel, [in:] The Dialogic Imagination, Austin 1981, p. 84-85.

Byzantium. Identity, Image, Influence. XIX. International Congress of Byzantine Studies, Major Papers, ed. F. Fledelius, Copenhagen 1996.

Christians Shaping Identity from the Roman Empire to Byzantium. Studies Inspired by Pauline Allen, ed. G. Dunn, W. MaYer, Leiden 2015 [= Supplements to Vigiliae Christianae, 132].

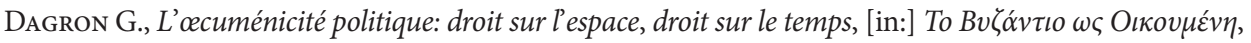
ed. E. Chrysos, Athens 2005 [= Institute for Byzantine Research, International Symposia, 16], p. 47-57.

From Hellenism to Islam. Cultural and Linguistic Change in the Roman Near East, ed. H.M. CоттоN, C. Hoyland, J.C. Price, D.J. Wasserstein, Cambridge 2009.

Geary P.J., The Myth of Nations. The Medieval Origins of Europe, Princeton 2002.

Grumel V., La Chronologie, Paris 1958 [= Traité d’études byzantines, 1].

Gumbrecht H.U., Zeitbegriffe in den Geisteswissenschaften heute, [in:] Akademie im Dialog, X, Vienna 2017 , p. 5-13.

Новзвашм E., The Invention of Tradition, Cambridge 1997.

Integration und Herrschaft. Ethnische Identitäten und soziale Organisation im Frühmittelalter, ed. W. Pohl, M. Diesenberger, Wien 2002 [= Forschungen zur Geschichte des Mittelalters, 3].

Koder J., "P

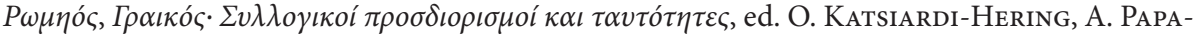
dia Lala, K. Nikolaou, V. Karamanolakis, Athens 2018, p. 73-84.

Koder J., Anmerkungen zum Awaren-Sgraffito von Sirmium, comm. R. Wedenig, [in:] Lebenswelten zwischen Archäologie und Geschichte. Festschrift für Falko Daim zu seinem 65. Geburtstag, ed. J. Drauschke et al., Mainz 2018 [= Monographien des Römisch-Germanischen Zentralmuseums, 150], p. 733-740.

Koder J., Byzantion wird Konstantinupolis: Anmerkungen zu Ortswahl und Namen, [in:] Constantinople réelle et imaginaire autour de l'oeuvre de Gilbert Dagron, ed. C. Morrisson, J.-P. Sodini (= "Travaux et mémoires du Centre de recherches d'histoire et civilisation byzantines" 22, 1), Paris 2018, p. 21-33. 
Koder J., Byzantium as Seen by Itself - Images and Mechanisms at Work, [in:] Proceedings of the $22^{\text {nd }}$ International Congress of Byzantine Studies Sofia, 22-27 August 2011, I. Plenary Papers, Sofia 2011, p. 69-81.

Koder J., Byzanz, die Griechen und die Romaiosyne - eine "Ethnogenese" der "Römer"?, [in:] Typen der Ethnogenese unter besonderer Berücksichtigung der Bayern, vol. I, ed. H. WOLfRAM, W. PoHL, Vienna 1990 [= Denkschriften der kaiserlichen Akademie der Wissenschaften, philosophisch-historische Classe, 201], p. 103-111.

KoDer J., Byzanz - römische Identität, christliche Ideologie und europäische Ausstrahlung, [in:] Kata$\log$ zur Ausstellung "Das Goldene Byzanz und der Orient", ed. F. DAIm, D. Heher, Schallaburg 2012, p. 27-41.

Koder J., Die Hellenis als Mitte der Ökumene: Theodoros Laskaris über den Ursprung von Philosophie, Weisheit und Wissenschaft, [in:] Myriobiblos. Essays on Byzantine Literature and Culture, ed. T. Antonopoulou, S. Kotzabassi, M. Loukaki, Berlin-New York 2015 [= Byzantinisches Archiv, 29], p. 195-210.

Koder J., Griechische Identitäten im Mittelalter. Aspekte einer Entwicklung, [in:] Byzantium State and Society. In Memory of Nikos Oikonomides, ed. A. AvrameA, A. Laiou, E. Chrysos, Athens 2003, p. 297-319.

Koder J., Remarks on the Linguistic Romanness in Byzantium, [in:] Transformations of Romanness, ed. W. Pohl, C. Gantner, C. Grifoni, M. Pollheimer-Mohaupt, Berlin-Boston 2018 [= Millenium Studies, 71], p. 111-121.

Koder J., Space and Identity - Byzantine Conceptions of Geographic Belonging, Opening lecture, [in:] From the Human Body to the Universe. Spatialities of Byzantine Culture, Symposium Uppsala University, 18-21 May 2017 (in print).

Koder J., Sprache als Identitätsmerkmal bei den Byzantinern. Auf-isti endende sprachenbezogene Adverbien in den griechischen Quellen, "Anzeiger der philosophisch-historischen Klasse" 147, 2, 2012, p. 5-37.

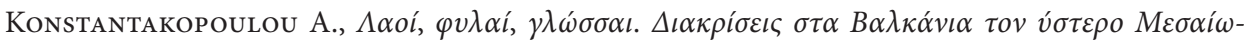
$v \alpha$, [in:] Toleration and Repression in the Middle Ages. In Memory of Leons Mavrommatis, ed. K. Nikolaou, Athens 2002, p. 327-355.

Lampe G.H.W., A Patristic Greek Lexicon, Oxford 1961.

Liddell H.G., Scott R., Jones H.S., McKenzie R., A Greek-English Lexicon, ${ }^{3}$ Oxford 1968.

Magdalino P., The End of Time in Byzantium, [in:] Endzeiten. Eschatologie in den monotheistischen Weltreligionen, ed. W. Brandes, F. Schmieder, Berlin 2008, p. 119-133.

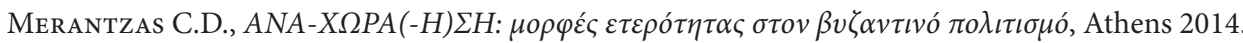

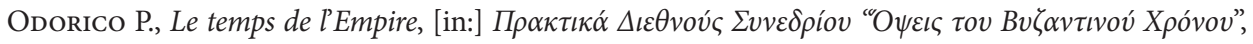
29-30 Maïov 2015, ed. E.G. Sarante, A. Dellaporta, T. Kollyropoulou, Athens 2018, p. 30-41.

Podskalsky G., Représentation du temps dans l'eschatologie impériale byzantine, [in:] Le temps chrétien de la fin de l'Antiquité au Moyen Âge - III ${ }^{e}-X I I I^{e}$ siècle (Colloque int. du CNRS 604), ed. J.-M. Leroux, Paris 1984, p. 439-450.

Podskalsky G., Ruhestand oder Vollendung? Zur Symbolik des achten Tages in der griechisch-byzantinischen Theologie, [in:] Fest und Alltag in Byzanz, ed. G. Prinzing, Munich 1990, p. 157-166, 216-219.

Riedel M.L.D., Leo VI and the Transformation of Byzantine Christian Identity. Writings of an Unexpected Emperor, Cambridge 2018. 
Schreiner P., Bilinguismus, Bilateralität und Digraphie in Byzanz, [in:] Historische Mehrsprachigkeit, ed. D. Boschung, C.M. Riehl, Aachen 2011 [= Zentrum für Sprachenvielfalt und Mehrsprachigkeit, Studien, 4], p. 125-141.

SCHreIner P., Ethnische Invektiven in der spätbyzantinischen Händlerwelt. Zum anonymen Poem im Marc. gr. XI, 6 aus dem dritten oder vierten Jahrzehnt des 14. Jahrhunderts, "Зборник Радова Византолошког Института" / "Zbornik Radova Vizantološkog Instituta” 50, 1/2, 2013 (= Mélanges Ljubomir Maksimović, ed. B. Krsmanović, S. Pirivatrić, vol. II), p. 763-778.

Scott R., Justinian's New Age and the Second Coming, [in:] R. Scotт, Byzantine Chronicles and the Sixth Century, Ashgate 2012, XIX, p. 1-22.

Scoтt R., The Treatment of Ecumenical Councils in Byzantine Chronicles, [in:] Christians Shaping Identity from the Roman Empire to Byzantium. Studies Inspired by Pauline Allen, ed. G. DunN, W. MaYer, Leiden 2015 [= Supplements to Vigiliae Christianae, 132], p. 364-384.

Sharf A., The Eighth Day of the Week, [in:] Kathegetria. Essays Presented to Joan Hussey for her $80^{\text {th }}$ Birthday, ed. J. Chrysostomides, Camberley 1988, p. 27-50.

Sim D.C., Jews, Gentiles and Ethnic Identity in the Gospel of Matthew, [in:] Christians Shaping Identity from the Roman Empire to Byzantium. Studies Inspired by Pauline Allen, ed. G. Dunn, W. Mayer, Leiden 2015 [= Supplements to Vigiliae Christianae, 132], p. 25-47.

Trapp E. et al., Lexikon zur byzantinischen Literatur, vol. I-II, Vienna 2001-2017.

Yeats W.B., A Vision, London 1937.

Zervas T.G., The Making of a Modern Greek Identity. Education, Nationalism, and the Teaching of a Greek National Past, [New York] 2012 [= East European Monographs, 790].

\begin{abstract}
The notion of identity (tautotes) was discussed, often in contrast to its opposite "otherness" (heterotes), not only during Classical Antiquity but also by Christian and Byzantine authors since Late Antiquity. Fundamental manifestations of every dimension of Byzantine identity - and in particular of collective identity - are language (including culture), religious (and political) commitment, space and time; these phenomena are deeply rooted in human consciousness.

This paper deals with the relation between identity and time (temporality). This relation is analysed on the basis of key terms like aion, kairos and chronos and the relations among them; the individualization of temporality becomes manifest in combinations of the mentioned terms with adjectives like emos or hemeteros. Not surprisingly, Byzantine authors - referring to passages in the Old and the New Testament - dealt mainly with eschatological (cosmic) time in relation to individual and collective identity, whereas the interest in the historical dimension of time was limited to authors of a small educated class.
\end{abstract}

Keywords: aïdiotes, aion, chronos, eschatology, heterotes, identity, kairos, otherness, Romaioi, tautotes, temporality, time.

Johannes Koder

Austrian Academy of Sciences Institute for Medieval Research Hollandstraße 11-13 1020 Vienna, Austria johannes.koder@oeaw.ac.at 